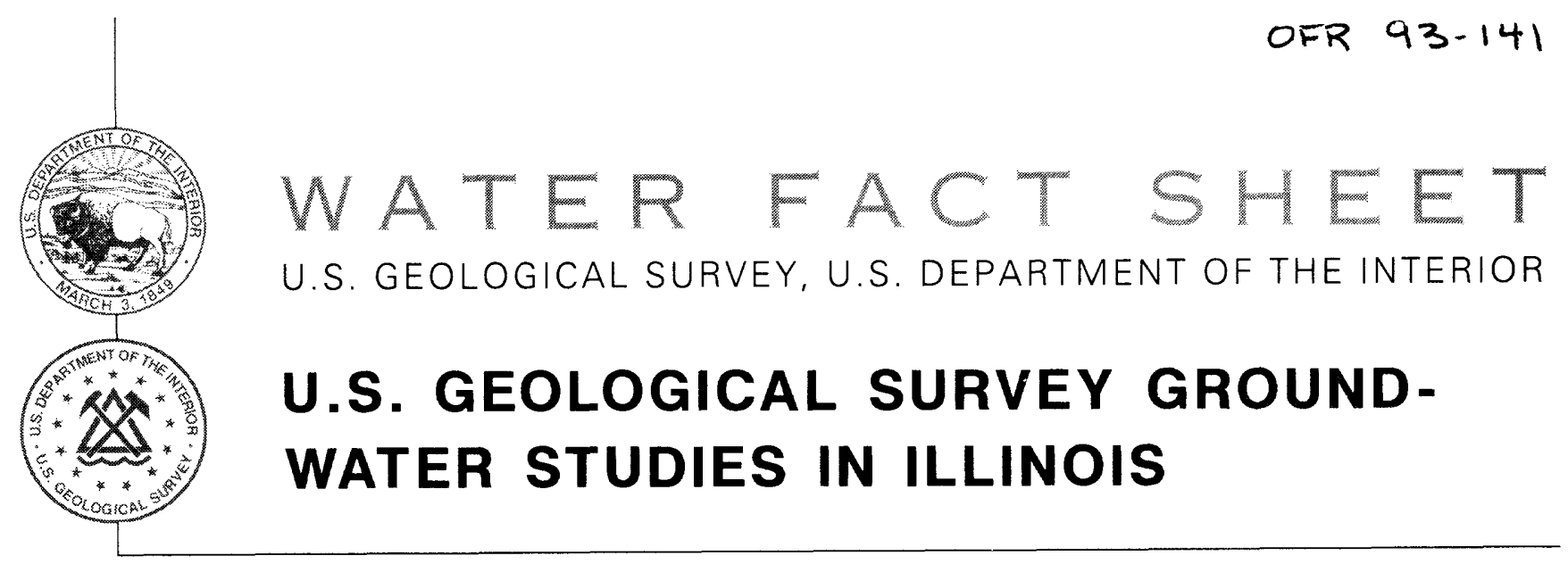

\section{GROUND-WATER ISSUES}

Ground water is an important source of water supply in Illinois. The largest amount of ground-water withdrawal is in the northern one-third of the State where aquifers to a depth of about 1,500 feet below land surface contain large quantities of potable water. Approximately 74 percent of the public water-supply systems in Illinois use ground water to supply potable water to more than 5.5 million people. Ground-water withdrawals account for almost 25 percent of the total water withdrawn for public water supplies in Illinois. Many public water-supply systems in the Chicago area have recently changed from using ground water pumped from wells to using water delivered from Lake Michigan. The major issues related to ground water in Illinois are:

- Water-quality degradation or contamination from point and nonpoint sources,

- Water availability, because of the lowering of ground-water levels in the bedrock aquifers in northeastern Illinois and elsewhere in the State where pumpage has exceeded aquifer recharge and the susceptibility of the limited surface-water supplies in central and southern Illinois to drought.

\section{U.S. GEOLOGICAL SURVEY PROGRAMS}

The U.S. Geological Survey (USGS), established in 1879, is the principal source of national scientific and technical expertise in the earth sciences in the fields of hydrology, geology, and cartography. The mission of the Water Resources Division (WRD) of the USGS is to develop and disseminate scientific information on the Nation's water resources. The activities of the Illinois District of the WRD are conducted by scientists, technicians, and support staff from offices in Urbana, De Kalb, and Mt. Vernon. The work activities conducted by District staff are generally confined to the State of Illinois. Ground-water scientists located in USGS research offices in Reston, Va., Lakewood, Colo., and Menlo Park, Calif., occasionally have participated in ground-water activities in the Hlinois District.

Hydrologic-data stations are maintained at selected locations throughout Illinois to record stream discharge and stage, ground-water levels, and the quality of surface water and ground water. Water-resources data for Illinois are stored on the National Water Information System (NWIS) data base maintained in the Illinois District office in Urbana and on the Water Data Storage and Retrieval System (WATSTORE) national data base maintained at the USGS headquarters in Reston, Va. These data are used by water planners, State and local agencies, and others involved in the decision-making processes involving water-resource issues of nlinois.

The USGS maintains two ground-water networks in Illinois: A long-term network of 13 wells to observe water-level fluctuations (an indicator of changes in ground- water storage resulting from climatic variability and pumpage) and to monitor water quality, and a network of 68 wells sampled periodically as part of the Mid-Continent Herbicide Initiative. Water-level and water-quality data commonly are integrated with other hydrologic information as part of ground-water studies to evaluate the availability and potability of the ground-water resources.

The USGS has conducted nearly 100 hydrologic studies in Illinois since 1955. In 1992, the USGS had cooperative agreements with 17 Federal, State, and local agencies to conduct 21 hydrologic studies in Illinois; 12 studies are concerned with ground-water quality and quantity. These studies provide needed information on local, State, regional, and national hydrologic problems. Ground-water studies in Illinois have included an examination of the effects of buried low-level radioactive waste on the ground-water resources near Sheffield and the Argonne National Laboratory near Chicago, and a regional appraisal of the ground-water resources in the deep sandstone aquifers underlying northern Illinois. Reports that describe the results of the work are published during and upon completion of USGS studies.

\section{U.S. Environmental Protection Agency Projects}

Thirty-six hazardous-waste sites in Illinois have been placed on the National Priorities List (NPL) under the Comprehensive Environmental Response, Compensation, and Liability Act of 1980-the Superfund Program, and 12 hazardous-waste sites are undergoing corrective action involving the study of ground-water contamination under the Resource Conservation and Recovery Act. Throughout the Nation, the U.S. Environmental Protection Agency (USEPA) has requested the technical assistance of the USGS in conducting hydrologic investigations at such sites. The Illinois District staff has cooperated with the USEPA, Region V, for the last 6 years by providing technical assistance on various activities relating to Remedial Investigation (RI) studies at NPL (Superfund) sites, conducting ground-water studies in areas with large concentrations of hazardous-waste sites, and instructing at USEPA training seminars. The Illinois District staff is currently cooperating with the USEPA on studies of ground-water flow and water quality of the shallow water-table aquifer in southern Cook County, the bedrock aquifers in the Rockford area, and the Galena-Platteville aquifer in north-central Illinois, and is providing technical assistance on RI studies at six Superfund sites.

\section{Statewide Ground-Water-Quality Monitoring}

As part of Illinois Public Act (P.A.) 83-1268, the Illinois Environmental Protection Agency (IEPA) was assigned the task of establishing a statewide ground-water-monitoring network. In 1984, a cooperative agreement was reached between the USGS and the IEPA, Division of Public Water Supplies, to conduct a 
ground-water-quality monitoring program using a network of public water-supply wells in the State. The IEPA used the water-quality data collected from the monitoring program to develop ground-water-quality standards for the State of Illinois. The Illinois Groundwater Protection Act, enacted in 1987, mandated a new and continual assessment of ground-water quality in Illinois. Water from 50 public water-supply wells is sampled on a quarterly basis and analyzed for inorganic and organic constituents, including volatile and semivolatile organic compounds and agricultural chemicals. The 50 wells were chosen by a stratified randomselection process on the basis of the total amount of ground-water withdrawals from each of five principal aquifers in Illinois (U.S. Geological Survey, 1985, p. 200).

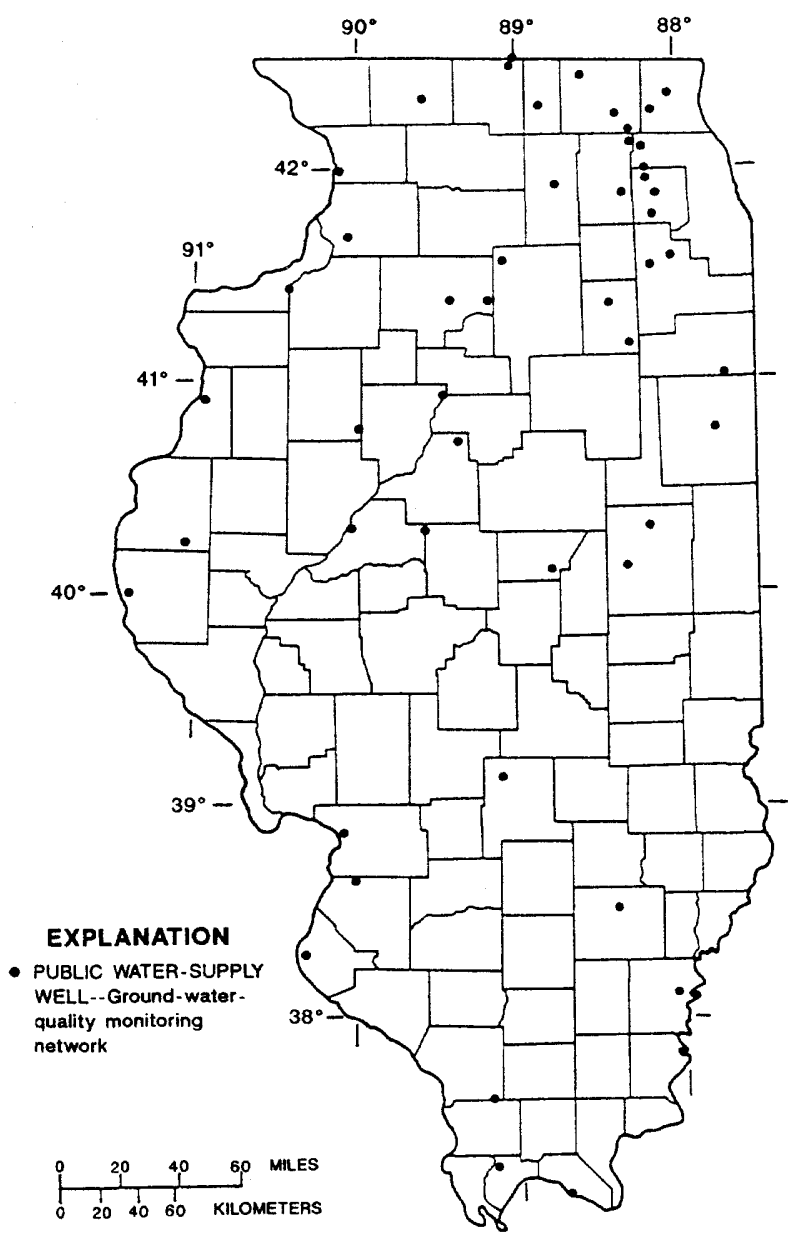

\section{GROUND-WATER MANAGEMENT}

The principal State agencies responsible for ground-water assessment, management, and protection programs in Illinois are the Department of Energy and Natural Resources, which includes the State Geological and State Water Surveys; the IEPA; the Department of Public Health; the Department of Transportation, Division of Water Resources; and the Pollution Control Board. The Department of Energy and Natural Resources is responsible for maintaining files of drillers' logs, and ground-water quality and pumpage records. The IEPA is responsible for pollution control and regulates public watersupply systems. The Department of Public Health operates laboratories for the analysis of voluntarily submitted water samples from private water-supply wells in the State and maintains the records of these water-quality analyses in their files. The Division of Water Resources is involved in water-quantity issues in Illinois, and the Pollution Control Board has the authority to issue regulations to restore, maintain, and enhance the purity of the waters of the State. The Illinois Groundwater Protection Act (P.A. 85-0863) mandates the establishment of wellhead-protection, or setback, zones within which potential contamination sources or routes will be regulated. Also, the location of new water-supply wells will be regulated to prevent their construction in areas where potential contamination sources or routes exist.

The USGS conducts ground-water studies for other Federal, State, and local agencies. The IEPA, the USEPA, the Illinois State Geological Survey, and the U.S. Fish and Wildlife Service have entered into interagency or cooperative cost-sharing agreements with the USGS to conduct ground-water studies in Illinois.

\section{SELECTED REFERENCES}

Balding, G.O., 1992, Water-resources activities of the U.S. Geological Survey in Illinois, 1991: U.S. Geological Survey Open-File Report 92-452, 98 p.

Nicholas, J.R., and Healy, R.W., 1988, Tritium migration from a low-level radioactive-waste disposal site near Chicago, Illinois: U.S. Geological Survey Water-Supply Paper 2333, 46 p.

Ryan, B.J., [ed], 1991, Results of hydrologic research at a low-level radioactive-waste disposal site near Sheffield, Illinois: U.S. Geological Survey Water-Supply Paper 2367, 73 p.

U.S. Geological Survey, 1984, National water summary, 1983--Hydrologic events and issues: U.S. Geological Survey Water-Supply Paper 2250, 243 p.

1985, National water summary, 1984--Hydrologic events, selected water-quality trends, and ground-water resources: U.S. Geological Survey Water-Supply Paper 2275, 467 p.

1988, National water summary, 1986--Hydrologic events and ground-water quality: U.S. Geological Survey Water-Supply Paper 2325, $560 \mathrm{p}$.

Voelker, D.C., Oberg, D.J., and Grober, M.J., 1988, Water-quality data from the observation-well network in Illinois, 1985-87: U.S. Geological Survey Open-File Report 87-538, 725 p.

Young, H.L., 1992, Summary of ground-water hydrology of the Cambrian-Ordovician aquifer system in the northern Midwest, United States: U.S. Geological Survey Professional Paper 1405-A, $55 \mathrm{p}$

Information on technical reports and data related to ground water in Illinois can be obtained from:

District Chief
U.S. Geological Survey, WRD
102 East Main Street, 4th Floor
Urbana, Illinois 61801
Chief
Illinois State Geological Survey
615 East Peabody Drive
Champaign, Ilinois 61820
Chief
Ilinois State Water Survey
2204 Griffith Drive
Champaign, Illinois 61820
Director
Water Resources Center
278 EASB, MC-635
1101 W. Peabody Drive
Urbana, Illinois 61801

Open-File Report 93-141

Charles Avery, 1994 